\title{
Composition of Triacylglycerols in Fats of Cow and Goat Milk Produced in Four Zones of Mexico
}

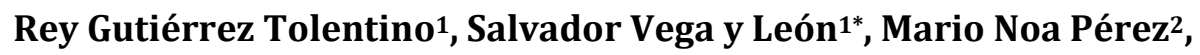 \\ Marta Coronado Herrera1, Acacia Ramírez Ayala ${ }^{1}$, José Jesús Pérez González', \\ Beatriz Schettino Bermúdez1, Rutilio Ortiz Salinas', Marcela Vazquez Francisca3 ${ }^{3}$, \\ Juan Gabriel Rivera Martínez \\ ${ }^{1}$ Departamento de Producción Agrícola y Animal, Universidad Autónoma Metropolitana-Xochimilco, México D.F., \\ México \\ ${ }^{2}$ Departamento de Salud Pública, Universidad de Guadalajara, Guadalajara, México \\ ${ }^{3}$ Maestría en Ciencias Agropecuarias, Universidad Autónoma Metropolitana-Xochimilco, México D.F., México \\ ${ }^{4}$ Departamento de Biología de la Reproducción, Universidad Autónoma Metropolitana-Iztapalapa, México D.F., \\ México \\ Email: ${ }^{*}$ svega@correo.xoc.uam.mx
}

Received 4 February 2015; accepted 14 April 2015; published 16 April 2015

Copyright (C) 2015 by authors and Scientific Research Publishing Inc.

This work is licensed under the Creative Commons Attribution International License (CC BY).

http://creativecommons.org/licenses/by/4.0/

(c) (i) Open Access

\section{Abstract}

The study of the triacylglycerols (TAG) by gas chromatography (GC) using capillary columns is an efficient technique for the determination of some characteristics of quality of fats and oils. The objective of the present study was to determine by GC the content of TAG present in fat of cow and goat milk produced in four zones of Mexico. According to criteria established in Mexican Standardization, 25 samples were obtained of $1 \mathrm{~L}$ of ultra-pasteurized cow milk (UHT) and 27 and 48 of raw cow and goat milk, respectively. The fat was extracted from all of the milk samples by detergent solution, and was stored at $-20^{\circ} \mathrm{C}$ until its analysis. The chromatographic conditions made it possible to identify and quantify TAG of 28 to 54 numbers of carbons, which were analyzed under descriptive and inferential statistical techniques. For the cow milk fat, the statistical analyses indicated significant difference $(p<0.05)$ in the TAG C34, C50 and C52, and for the goat milk fat in the TAG of C36 to C52. No equality of means was found among the TAG of the cow and goat milk fat. This study offers an advance in the characterization of the TAG present in the cow and goat milk fat produced in Mexico.

\section{Keywords}

Cow Milk, Goat Milk, Mexico, Triacylglycerols

\footnotetext{
${ }^{*}$ Corresponding author.
}

How to cite this paper: Tolentino, R.G., León, S.V., Pérez, M.N., Herrera, M.C., Ayala, A.R., González, J.J.P., Bermúdez, B.S., Salinas, R.O., Francisca, M.V. and Martínez, J.G.R. (2015) Composition of Triacylglycerols in Fats of Cow and Goat Milk Produced in Four Zones of Mexico. Food and Nutrition Sciences, 6, 555-561. http://dx.doi.org/10.4236/fns.2015.66058 


\section{Introduction}

The United Nations Organization for Food and Agriculture (FAO) estimated for 2012 a world cow milk production of 754 million tons. Of this production, the United States is the country that produced the most (12\%), followed by India, China, Brazil and Russia, with 54, 37, 32 and 31 million tons, respectively. Mexico produced approximately 11 million tons [1] [2]. However, world milk production is variable through time, for example, taking a period of 6 years, statistics indicate that some countries have reduced production, while others have increased it; such is the case of the Ukraine and Australia, which produced 13 and 11 million tons in 2003, respectively, while in 2009 they had a milk production of 86, 46, 28, 29 and 11, respectively [3]. In the case of goat milk, world production for 2005 was 12.5 million tons, of which Asia (principally India and Bangladesh) produced 53\%, Africa (Sudan outstanding) 23\%, Europe (France, and Spain) 21\%, and America represented 3\% of world production [4]. With data of the FIL, a gradual increment has been observed in world production of goat milk, obtaining a production of 11.6 million tons in 1998 and 13.8 in 2008 [5]. In Mexico, production has also increased due to the growing demand of raw milk and some derivates such as cheese, cajeta (caramelized goat milk) and other sweets [6] [7], representing approximately 1.5\% of world production. Official data registered 152,332 tons in 2013 [2].

In Mexico, principally in the Mexican Highland and the northern part of the country, the Holstein race is the most important in cow milk production and the races Saanen and French Alpine for goat milk [8] [9].

The above data highlight the importance of milk production in Mexico and the world, and thus some characteristics of quality and safety should be considered with the purpose of guaranteeing healthy products to the consumer of dairy products. Within the criteria of quality, microbiological, chemical, (content of protein, fat and lactose) and physical characteristics such as cryoscopic point, and density are considered, among others. However, there are other variables that day by day are required and incorporated in the food industry, such is the case of pernicious substances (pesticides, polychlorinated biphenyls, etc.) and/or health promoters (some fatty acids, TAG and sterols).

The analytical techniques which permit an evaluation of quality and safety of milk require knowledge and basic equipment of relatively low cost, such as contents of fat, protein and lactose; $\mathrm{pH}$; acidity; caseins; among others. However, there are also other complementary analyses which are now required in the dairy industry to guarantee safety as well as quality of the products. Among those to be considered are the analyses of proteins by capillary electrophoresis, microbiological analyses through molecular biology, toxic residuals and composition of lipids by different methods, such as fine layer chromatography, gas chromatography and/or high performance liquid chromatography. Of these analyses, the composition of lipids represents a priority area in many research centers throughout the world.

\section{Materials and Methods}

\subsection{Taking of Samples}

1) Ultra-pasteurized milk fat (UHT) $(n=25)$. Samples of 1 liter of UHT milk were collected every seven days during 10 weeks, from three dairy industries which market their products in the state of Jalisco (according to the availability of the market the number of samples for each industry was: $A=8, B=10$ and $C=7$ ). The collection was made according to the methodology proposed by the International Dairy Federation and Mexican Norm [10] [11]. The fatty matter was extracted by means of a detergent solution [12] and was maintained at $-20^{\circ} \mathrm{C}$ until its analysis.

2) Raw cow milk fat $(n=27)$. Samples of 1 liter of raw milk were obtained every seven days during 9 weeks, from three intensive production units (stables) of the state of Jalisco. The fatty matter was extracted and stored under conditions similar to those of the UHT milk fat.

3) Raw goat milk fat $(n=48)$. Samples of 1 liter of raw milk were obtained every seven days during 12 weeks, from four zones of three states of Mexico (Apaseo el Grande, Guanajuato; Topilejo, D.F.: Celaya, Guanajuato and Jalisco, Jalisco). The four sampling zones have milk producing goats of the races Saanen and French Alpine. The fatty matter was extracted and stored under conditions similar to those of the UHT milk fat.

\subsection{Chromatographic Analysis}

A Perkins Elmer gas chromatograph model Autosystem 9000 was used, with flame ionization detector and area 
integrator PE Nelson 1022.

Operation conditions: Temperature of the injector (split-splitless): $340^{\circ} \mathrm{C}$; temperature of the detector (DIF): $350^{\circ} \mathrm{C}$; gas drag flow (helium): $1 \mathrm{~mL} / \mathrm{min}$; oven temperature program: temperature $1=200^{\circ} \mathrm{C} 0 \mathrm{~min}$, with increment of $5^{\circ} \mathrm{C} / \mathrm{min}$ to $325^{\circ} \mathrm{C}$. Temperature $2=325^{\circ} \mathrm{C} 6 \mathrm{~min}$. Total run time 31 minutes. Injection volume: $1 \mu \mathrm{L}$. Silicon methyl phenyl column at 5\%, intermediate polarity HP5. Length $=2 \mathrm{~m} \times 0.25$ m.m.d.i. $\times 0.25 \mu \mathrm{m}$ layer thickness. To identify and quantify the TAG, the chromatograms were compared (retention times and area of peaks) obtained from the different fat samples with the chromatogram of the mixture of standards of TAG.

\subsection{Preparation of TAG Standard and Determination of Correction Factors}

The TAG standard of $100 \mathrm{mg}$ at 99\% 178-11: Tricaprylin (C8:0) 20\%; tricaprin (C10:0) 20\%; trilaurin (C12:0) 20\%; trimyristin (C14:0) 20\%; tripalmitin (C16:0) 20\% was from the commercial firm Sigma Chemical Co. St Louis MO 63178 USA. The vial of $100 \mathrm{mg}$ ( $20 \mathrm{mg}$ of each one of the 5 triacylglycerols) was dissolved in $5 \mathrm{~mL}$ of n-hexane. $1 \mu \mathrm{L}$ of the solution was injected five times to determine retention time and the percentage of area for every TAG. Average retention time was calculated, and correction factors were calculated considering the response factor for the trilaurin (C36) as 1.0, and using the following formula:

$$
f_{x}=C X / C 36 * A_{C 36} / A_{C X}
$$

where:

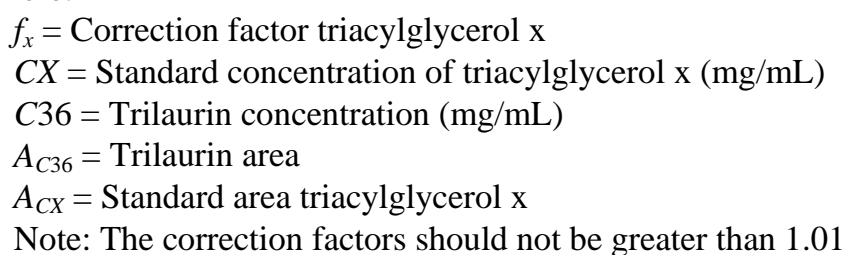

\subsection{Statistical Techniques}

Descriptive statistic, t-student test for comparison of means of independent samples, one track analysis of variance (ANOVA) followed by a Tukey test for comparison of means. For the statistical analysis the statistical program used was SPSS version 21.0 for Windows.

\section{Results}

Table 1 presents the mean values (\% w/w) and standard deviations of the contents of TAG in the fats of ultrapasteurized cow milk of the three selected industries (A, B and C), as well as in the raw cow milk; fourteen TAG were identified and quantified with even numbers of carbon from 28 to 54 (C28 to C54).

Table 2 shows the mean values and standard deviations of the TAG found in the fat of goat milk of the four zones studied. As can be observed, as in the cow milk, 14 TAG were identified and quantified with even carbon numbers of 28 to 54 .

The distribution of the global mean values of TAG in the two types of milk is represented in Figure 1. By visual inspection, it is observed that both milks form a distribution similar to C28 to C44, but different in the rest of the TAG.

\section{Discussion}

The composition of the TAG identified in the cow milk was similar to what was informed by Precht for samples of bovine milk [13]. The standard deviations showed low dispersion in the composition of the TAG, except for the TAG with 34 carbons, which in general terms, is similar to what was informed by Timms, Pinto et al., Fontecha et al., Gutiérrez et al. and Zhou et al. [14]-[18]. In Table 1 it is observed that the values of TAG in ultra-pasteurized and raw milk were consistent. However, the analysis of variance (ANOVA) showed significant difference ( $p<0.05)$ among the means of the TAG of high molecular weight C50 and C52; the maximum mean values were found in industry $\mathrm{C}$, being similar $(\mathrm{p} \geq 0.05)$ to industry $\mathrm{B}$ in $\mathrm{C} 50$ and to industry B and raw milk in C52. For the case of the TAG of medium weight, the ANOVA indicated statistical significance only for C34, but in a marginal way $(p=0.05)$, industry $C$ presented minimum mean value having equality $(p \geq 0.05)$ with the 
Table 1. Mean values and standard deviations of TAG (\% w/w) fat present in cow milk (ultra-pasteurized and raw).

\begin{tabular}{lcccc}
\hline TAG & $\begin{array}{c}\text { Industry A } \\
(\mathrm{n}=8)\end{array}$ & $\begin{array}{c}\text { Industry B } \\
(\mathrm{n}=10)\end{array}$ & $\begin{array}{c}\text { Industry C } \\
(\mathrm{n}=9)\end{array}$ & $\begin{array}{c}\text { Raw cow milk } \\
(\mathrm{n}=27)\end{array}$ \\
\hline C28 & $2.67 \pm 0.35$ & $2.22 \pm 0.50$ & $2.16 \pm 0.18$ & $2.31 \pm 0.45$ \\
C30 & $4.07 \pm 0.65$ & $3.77 \pm 0.48$ & $3.42 \pm 0.26$ & $3.79 \pm 0.48$ \\
C32 & $6.17 \pm 0.58$ & $5.66 \pm 0.66$ & $5.51 \pm 0.39$ & $5.95 \pm 1.02$ \\
C34 & $11.17 \mathrm{a} \pm 0.99$ & $10.24 \mathrm{ab} \pm 1.15$ & $9.42 \mathrm{~b} \pm 0.79$ & $10.26 \mathrm{ab} \pm 1.19$ \\
C36 & $16.87 \pm 0.93$ & $15.91 \pm 1.52$ & $15.50 \pm 0.26$ & $15.70 \pm 1.02$ \\
C38 & $16.77 \pm 2.00$ & $17.19 \pm 0.90$ & $17.12 \pm 0.61$ & $16.73 \pm 0.66$ \\
C40 & $12.13 \pm 0.33$ & $12.11 \pm 0.69$ & $11.73 \pm 0.45$ & $12.34 \pm 0.79$ \\
C42 & $6.12 \pm 0.49$ & $6.44 \pm 0.57$ & $6.13 \pm 0.08$ & $6.56 \pm 0.52$ \\
C44 & $4.58 \pm 0.49$ & $4.93 \pm 0.60$ & $4.74 \pm 0.27$ & $5.10 \pm 0.49$ \\
C46 & $4.48 \pm 0.44$ & $4.83 \pm 0.59$ & $4.96 \pm 0.30$ & $5.02 \pm 0.56$ \\
C48 & $4.93 \pm 0.48$ & $5.40 \pm 0.86$ & $5.88 \pm 0.30$ & $5.39 \pm 0.64$ \\
C50 & $5.28 \mathrm{a} \pm 0.63$ & $5.84 \mathrm{ab} \pm 1.07$ & $6.70 \mathrm{~b} \pm 0.18$ & $5.70 \mathrm{a} \pm 0.73$ \\
C52 & $3.66 \mathrm{a} \pm 0.74$ & $4.15 \mathrm{ab} \pm 1.08$ & $5.16 \mathrm{~b} \pm 0.27$ & $3.95 \mathrm{ab} \pm 0.72$ \\
C54 & $1.09 \pm 0.34$ & $1.26 \pm 0.45$ & $1.54 \pm 0.16$ & $1.20 \pm 0.29$ \\
\hline
\end{tabular}

Mean values in rows with different letters indicate significant difference $(\mathrm{p}<0.05)$.

Table 2. Mean values of TAG (\% w/w) fat present in raw goat milk produced in four regions of Mexico.

\begin{tabular}{|c|c|c|c|c|}
\hline TAG & $\begin{array}{l}\text { Apaseo } \\
(\mathrm{n}=12)\end{array}$ & $\begin{array}{l}\text { Topilejo } \\
(\mathrm{n}=12)\end{array}$ & $\begin{array}{c}\text { Celaya } \\
(\mathrm{n}=12)\end{array}$ & $\begin{array}{c}\text { Jalisco } \\
(\mathrm{n}=12)\end{array}$ \\
\hline $\mathrm{C} 28$ & $3.33 \pm 0.90$ & $2.23 \pm 1.24$ & $2.99 \pm 0.31$ & $2.47 \pm 0.94$ \\
\hline C30 & $5.78 \pm 1.12$ & $5.09 \pm 0.71$ & $4.71 \pm 0.40$ & $4.64 \pm 0.88$ \\
\hline C32 & $7.01 \pm 1.04$ & $6.66 \pm 0.79$ & $5.93 \pm 0.38$ & $6.14 \pm 0.78$ \\
\hline C34 & $9.10 \pm 0.67$ & $8.26 \pm 1.10$ & $8.75 \pm 0.41$ & $8.40 \pm 0.95$ \\
\hline C36 & $12.66 \mathrm{ab} \pm 0.99$ & $12.36 \mathrm{ab} \pm 1.00$ & $13.62 b \pm 1.33$ & $12.06 \mathrm{a} \pm 0.98$ \\
\hline C38 & $15.51 \mathrm{ab} \pm 1.41$ & $14.74 \mathrm{a} \pm 0.63$ & $17.03 b \pm 0.92$ & $14.98 \mathrm{a} \pm 1.10$ \\
\hline $\mathrm{C} 40$ & $14.64 \mathrm{ab} \pm 1.30$ & $14.82 \mathrm{ab} \pm 0.76$ & $16.19 b \pm 0.63$ & $14.40 \mathrm{a} \pm 1.23$ \\
\hline C42 & $11.87 \mathrm{a} \pm 0.92$ & $13.08 \mathrm{ab} \pm 0.58$ & $13.38 b \pm 0.24$ & $12.95 a b \pm 0.94$ \\
\hline C44 & $8.62 \mathrm{a} \pm 0.58$ & $9.60 \mathrm{ab} \pm 0.45$ & $9.14 \mathrm{ab} \pm 0.18$ & $9.75 b \pm 0.87$ \\
\hline C46 & $4.59 \mathrm{ab} \pm 1.37$ & $5.95 b \pm 0.79$ & $4.28 \mathrm{a} \pm 0.45$ & $5.97 b \pm 0.74$ \\
\hline C48 & $3.01 \mathrm{ab} \pm 0.66$ & $3.79 b \pm 0.92$ & $2.30 \mathrm{a} \pm 0.60$ & $3.85 b \pm 0.69$ \\
\hline C50 & $2.35 a b \pm 0.93$ & $2.44 \mathrm{ab} \pm 0.89$ & $1.34 \mathrm{a} \pm 0.46$ & $2.80 \mathrm{~b} \pm 0.80$ \\
\hline C52 & $1.35 \mathrm{ab} \pm 0.71$ & $0.91 \mathrm{ab} \pm 0.63$ & $0.34 \mathrm{a} \pm 0.30$ & $1.42 b \pm 0.71$ \\
\hline C54 & $0.18 \pm 0.22$ & $0.07 \pm 0.12$ & $0.01 \pm 0.01$ & $0.16 \pm 0.18$ \\
\hline
\end{tabular}

Mean values in rows with different letters indicate significant difference $(\mathrm{p}<0.05)$.

values found in industry B and raw milk. The values and differences found in this study are quantitatively different from what was informed in another work made for UHT milk fats commercialized in Mexico City and raw milk produced in Mexico City, Hidalgo and the State of Mexico [17]. Particularly for the TAG C34, C36, C38 and C40, the maximum mean values $(11.17,16.87,17.19$ and $12.34 \% \mathrm{w} / \mathrm{w}$, respectively) were found in this study, while the minimum mean values of C48, C50 and C52 (8.15, 14.56 and $16.68 \%$ w/w, respectively, were higher in the study of Gutiérrez et al. [17]. These differences show that the origin factor is determinant in the content of TAG present in the fats of milks produced in different regions. Table 3 presents the values of TAG obtained in various studies made in different countries. It can be observed that the factors time, origin and race have an effect on the composition of the TAG in the milk. 


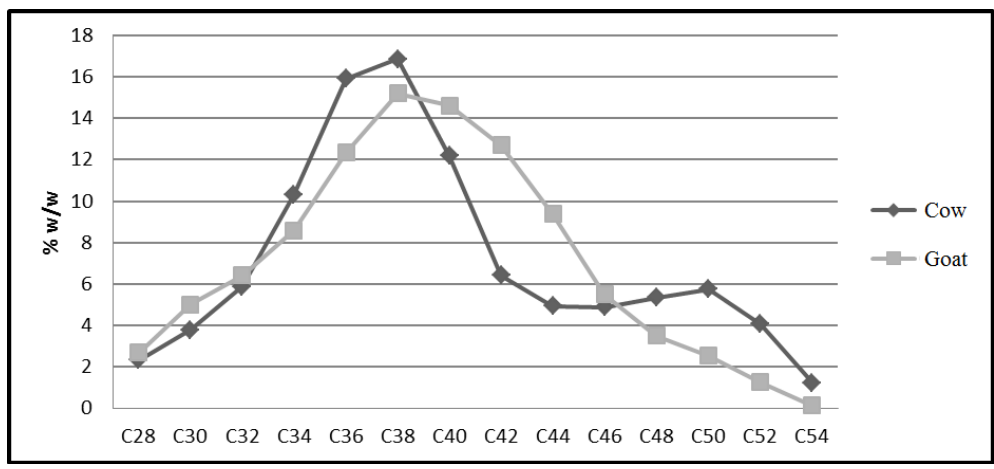

Figure 1. Mean values of TAG $(\% \mathrm{w} / \mathrm{w})$ fat present in raw cow $(n=27)$ and goat $(n=48)$ produced in four regions of Mexico.

Table 3. Mean values of TAG (\% w/w) fat present in cow's milk in Mexico and other countries.

\begin{tabular}{lccccccc}
\hline TAG & Mexico $^{*}$ & Australia $^{*}$ & Chile $^{* *}$ & Holland $^{\S}$ & United States $^{\epsilon}$ & Mexico $^{\text {s }}$ & Switzerland $^{\varepsilon}$ \\
\hline C28 & 2.34 & 0.54 & 0.68 & 0.56 & 1.95 & 0.45 & 0.61 \\
C30 & 3.79 & 1.03 & 1.28 & 1.12 & 2.71 & 0.58 & 1.19 \\
C32 & 5.88 & 2.33 & 2.66 & 2.46 & 5.12 & 1.45 & 2.47 \\
C34 & 10.32 & 5.45 & 5.83 & 5.72 & 10.24 & 3.41 & 5.86 \\
C36 & 15.92 & 10.52 & 10.96 & 10.44 & 15.54 & 7.11 & 11.04 \\
C38 & 16.87 & 13.13 & 14.82 & 12.27 & 14.43 & 11.26 & 13.30 \\
C40 & 12.19 & 10.52 & 11.98 & 9.66 & 10.52 & 10.68 & 10.45 \\
C42 & 6.42 & 6.31 & 7.37 & 6.83 & 8.76 & 7.26 & 7.33 \\
C44 & 4.94 & 5.57 & 5.98 & 6.55 & 8.29 & 5.27 & 6.84 \\
C46 & 4.89 & 6.38 & 6.19 & 7.43 & 7.75 & 6.59 & 7.59 \\
C48 & 5.36 & 8.44 & 7.43 & 9.26 & 5.64 & 9.34 & 9.14 \\
C50 & 5.76 & 11.74 & 10.28 & 11.33 & 3.68 & 13.43 & 11.07 \\
C52 & 4.07 & 11.29 & 9.66 & 10.33 & 1.12 & 14.64 & 9.47 \\
C54 & 1.23 & 5.96 & 4.19 & 4.90 & 0.12 & 8.61 & 3.64 \\
\hline
\end{tabular}

*In this study; ${ }^{\mathrm{q}}[14] ;{ }^{* *}[15] ;{ }^{\S}[23] ;{ }^{€}[20] ;{ }^{\mathrm{s}}[17] ;{ }^{\mathrm{E}}[19]$.

In another study made in Switzerland with cow milk fat, it was observed that, as in the present work, the highest values of TAG were presented by C36, C38 and C40, with an interval of 10.45 to $13.30 \%$ w/w, with the maximum value for C38 (13.30 \% w/w) [19]. In the United States, Depeters et al. informed maximum levels in the same TAG, although the highest value was presented by C36 $(15.54 \% \mathrm{w} / \mathrm{w})$ [20]. In both studies the dairy cows were fed diets with different sources of lipids (seeds of cotton, sunflower and soybean), which explains the effect of the modification of the component of the diet of the animal on the profiles of fatty acids and TAG. The values of TAG presented in Table 3 placed C38 as maximum value (16.87\% w/w), coinciding with what was informed by Contarini et al. and Gutiérrez et al. [17] [19].

In goat milk, its TAG composition did not present a bimodal distribution like cow milk, the maximum values were found in the TAG C38 and C40 (Table 2 and Figure 1). According to the literature consulted there are studies with unimodal and bimodal TAG distributions, and with maximums and minimums in different TAG. Examples of this are found in the works made in Spain by Fontecha et al. and Fontecha et al. in which a unimodal tendency was found in the TAG contents of goat milk with maximums in TAG C40, C42 and C44, and in a study carried out in the United States, a bimodal distribution was found, very similar to what was observed for cow milk, with maximums in TAG C36, C38 and C40 and a minimum in C42, C44, C46 and C48 [21]-[23]. Smiddy et al. registered in goat milk fat from Holland maximum levels in C38, C40 and C42 with values of $11.85,12.14$ and $11.14 \% \mathrm{w} / \mathrm{w}$, respectively [24]. 
The ANOVA gave significant differences $(\mathrm{p}<0.05)$ for the TAG interval of C36 to C52, with the milk fat produced in Celaya having the maximum mean values in the TAG of C36 to C42, and the minimum mean values in the TAG of C46 to C52. These results are understandable, if it is considered that race and origin are determinant factors of milk composition and consequently of its triglyceric content.

It was observed, in general terms, that the sum of the TAG intervals of short chain (C28 to C34), medium chain (C38 to C44) and long chain (C46 to C54) presented a pattern in goat milk similar to the values informed by Fontecha et al. [16]. The percentages for this study were C38-C34 $=22.7$, C36-C44 $=64.3$ and C46-C54 = 12.9 , which is explainable if it is considered that the fatty acids that are predominantly present in goat milk fat are of short, medium and long chain, from acetic to oleic [25] [26].

In Mexico there are no studies on the levels of TAG in goat milk, however, the mean values found in this study have a certain similarity, but also some differences to what was informed by other authors in Spain, the United States and Holland [16] [22] [24]. In a study made by Fontecha et al., it is demonstrated that the TAG with highest values present in goat milk fat are C36 to C44, with a maximum value in C40 (12.62 \% w/w) [23]. It is imperative to mention that the value of C40 is not very far from what was found for C38 $(12.08 \% \mathrm{w} / \mathrm{w})$ and C42 $(12.51 \% \mathrm{w} / \mathrm{w})$. In fact, because of the closeness of the values, it could be considered that there is no statistical difference between them. In this study the maximum value corresponded to C38 (17.03\% w/w).

Finally, the t-student test made it possible to define that there is no statistical difference $(p \geq 0.05)$ between the means of TAG of the (C28 TO C54) of the cow and goat milk. These results are congruent with what was reported in the literature [16] [24] and are relatively to explain, given that on one hand it has been informed that the percentage of the goat milk fat is three times more than in cow milk. It has also been documented by means of stereospecific analysis of fatty acids in the three positions of the stereochemical analysis of the glycerol, that the contents of fatty acids are different in the milks produced by different mammals [22] [27] [28]. In Figure 1 it is observed that the contents of TAG C34, C36, C38, C48 C50 and C52 are notably higher in cow milk fat, while the contents of C42 and C44 are higher in goat milk fat.

\section{Conclusion}

The chromatographic analysis recorded TAG of 28 to 54 carbons in fats of cow and goat milk. For the cow milk fat, the statistical analysis indicated significant to 95\% in the TAG C34, C50 and C52, and for the goat milk fat in the TAG of C36 to C52.

This study offers an advance in the characterization of the TAG present in the cow and goat milk fat produced in Mexico.

\section{References}

[1] FAO (2012) Organización de las Naciones Unidas para la Alimentación y Agricultura. Producción y Productos Lácteos. http://www.fao.org/agriculture/dairy-gateway/produccion-lechera

[2] SIAP. Servicio de Información Agroalimentaria y Pesquera. SAGARPA (2014) Panorama de la lechería en México, 2014. www.siap.sagarpa.gob.mx

[3] Pestana, J.L. (2010) Presente y futuro de la lechería en las Américas y el Mundo. Proceeding of 11th Congreso PanAmericano de Leche, Belo Horizonte, 22-25 March 2010, 1-17.

[4] FAO (2008) Statistics Databases (FAOSTAT). http://faostat.fao.org/site/DesktopDefault.aspx?PageID=339\&lang=es

[5] International Dairy Federation/Federación Internacional de Lechería (IDF/FIL) (2008) The World Dairy Situation. Bulletin of the International Dairy Federation 432/2008. www.fil-idf.org

[6] Trujillo, A. and Almudena, F. (2004) Consumo de queso de cabra en la Ciudad de Tequisquiapan, Qro. México. Proceeding of XIX Reunión Nacional sobre Caprinocultura, Acapulco, 13-15 October 2004.

[7] Flores, M.A., Pérez, R., Basurto, M. and Jurado, M.R. (2009) La leche de cabra y su importancia en la nutrición. Tecno-Ciencia, 3, 107-113.

[8] Gurría, F. (2004) Situación del sector caprino en México. Revista Cabras 2004, Marzo-Abril, 27-28.

[9] Cesín, A. and Cervantes, F. (2009) Ganadería lechera mexicana, situación actual, retrovisión y perspectivas. In: Cesín, A., Cervantes, F. and Álvarez, A., Eds., La lechería familiar en México, UACH, CIESTAAM, CP, UAM, CONACYT, PORRÚA, México, 13-29.

[10] International Dairy Federation/Federación Internacional de Lechería (IDF/FIL) (1995) Milk and Milk Products. Guidance Sampling. FIL-IDF Standard 50C. 
[11] NMX-F-718-COFOCALEC-2006 (2006) Sistema producto leche-Alimentos-Lácteos-Guía para el muestreo de leche y productos lácteos. México.

[12] Frank, R., Smith, E.H., Brawn, H.E., Holdrinet, A. and McWade, J.W. (1975) Organochlorine Insecticides and Industrial Pollutants in the Milk Supply of the Southern Region of Ontario, Canada. Journal of Milk and Food Technology, 38, 65-72.

[13] Precht, D. (1992) Detection of Foreign Fat in Milk Fat I. Qualitative Detection by Triacylglycerol Formulae. Zeitschrift für Lebensmittel-Untersuchung und Forschung, 194, 1-8. http://dx.doi.org/10.1007/BF01191031

[14] Timms, R.E. (1980) Detection and Quantification of Non-Milk Fat in Mixtures of Milk and Non-Milk Fats. Journal of Dairy Research, 47, 295-303. http://dx.doi.org/10.1017/S002202990002118X

[15] Pinto, M.C., Fernández, P.R. and Villanueva, B. (1987) Detección y cuantificación de adulteraciones en grasa láctea. Análisis de regresión múltiple. Agro Sur, 15, 32-38.

[16] Fontecha, J., Mayo, I., Toledano, G. and Juárez, M. (2006) Triacylglycerol Composition of Protected Designation of Origin Cheeses during Ripening. Authenticity of Milk Fat. Journal of Dairy Science, 89, 882-887. http://dx.doi.org/10.3168/jds.S0022-0302(06)72152-X

[17] Gutiérrez, R., Vega, S., Díaz, G., Sánchez, J., Coronado, M., Ramírez, A., Pérez, J., González, M. and Schettino, B. (2009) Detection of Non-Milk Fat in Milk Fat by Gas Chromatography and Linear Discriminant Analysis. Journal of Dairy Science, 92, 1846-1855. http://dx.doi.org/10.3168/jds.2008-1624

[18] Zhou, Q., Gao, B., Zhang, X., Xu, Y., Shi, H. and Yu, L. (2014) Chemical Profiling of Triacylglycerols and Diacylglycerols in Cow Milk Fat by Ultra-Performance Convergence Chromatography Combined with a Quadrupole Timeof-Flight Mass Spectrometry. Food Chemistry, 143, 199-204.

[19] Contarini, G., Toppino, P., Leardi, R., Polidori, F., Savoini, G. and Bertocchi, L. (1996) Lipid Supplementation of Dairy Cows' Diets: Effects on Milk Fat Composition. Journal of Agricultural and Food Chemistry, 44, 3507-3511. http://dx.doi.org/10.1021/jf960022y

[20] Depeters, E.J., Germán, J.B., Taylor, S.J., Essex, S.T. and Pérez-Monti, H. (2001) Fatty Acid and Triglycerides Composition of Milk Fat from Lactating Holstein Cows in Response to Supplemental Canola Oil. Journal of Dairy Science, 84, 929-936. http://dx.doi.org/10.3168/jds.S0022-0302(01)74550-X

[21] Fontecha, J., Ríos, J.J., Lozada, L., Fraga, M.J. and Juárez, M. (2000) Composition of Goat’s Milk Fat Triglycerides Analysed by Silver Ion Adsorption-TLC and GC-MS. International Dairy Journal, 10, 119-128. http://dx.doi.org/10.1016/S0958-6946(00)00026-1

[22] Park, Y.W., Juárez, M., Ramos, M. and Haenlein, G.F.W. (2007) Physico-Chemical Characteristics of Goat and Sheep Milk. Small Ruminant Research, 68, 88-113. http://dx.doi.org/10.1016/j.smallrumres.2006.09.013

[23] Fontecha, J., Díaz, V., Fraga, M.J. and Juárez, M. (1998) Triglyceride Analysis by Gas Chromatography in Assessment of Authenticity of Goat Milk Fat. Journal of the American Oil Chemists' Society, 75, 1893-1896. http://dx.doi.org/10.1007/s11746-998-0347-6

[24] Smiddy, M.A., Huppertz, T. and Van Ruth, S.M. (2012) Triacylglycerol and Melting Profiles of Milk Fat from Several Species. International Dairy Journal, 24, 64-69. http://dx.doi.org/10.1016/j.idairyj.2011.07.001

[25] Blasi, F., Montesano, D., De Angelis, M., Maurizi, A, Ventura, F., Cossignani, L., Simonetti, M.S. and Damiani, P. (2008) Results of Stereospecific Analysis of Triacylglycerol Fraction from Donkey, Cow, Ewe, Goat and Buffalo Milk. Journal of Food Composition and Analysis, 21, 1-7. http://dx.doi.org/10.1016/j.jfca.2007.06.005

[26] Beccaria, M., Sullini, G., Cacciola, F., Donato, P., Dugo, P. and Mondello, L. (2014) High Performance Characterization of Triacylglycerols in Milk and Milk-Related Samples by Liquid Chromatography and Mass Spectrometry. Journal of Chromatography A, 1360, 172-187. http://dx.doi.org/10.1016/j.chroma.2014.07.073

[27] Ceballos, L.S., Morales, E.R., de la Torre Adarve, G., Castro, J.D., Martínez, L.P. and Sanz, M.R.S. (2009) Composition of Goat and Cow Milk Produced under Similar Conditions and Analyzed by Identical Methodology. Journal of Food Composition and Analysis, 22, 322-329. http://dx.doi.org/10.1016/j.jfca.2008.10.020

[28] Gastaldi, D., Medana, C., Giancotti, V., Aigotti, R., Dal Bello, F. and Baiocchi, C. (2011) HPLC-APCI Analysis of Triacylglycerols in Milk Fat from Different Sources. European Journal of Lipid Science and Technology, 113, $197-207$. http://dx.doi.org/10.1002/ejlt.201000068 